\title{
Застосування сучасних інформаційних технологій у кардіореабілітації: огляд зарубіжного досвіду
}

\author{
УДК: 796:615.825+616-005.4+616-08
}

\author{
В. П. Костенко, М. С. Балаж
}

Національний університет фізичного виховання і спорту України, Київ, Україна

\begin{abstract}
Резюме. Мета. За даними літературних джерел розглянути сучасні підходи до можливості застосування інформаційних технологій у кардіореабілітації хворих на ішемічну хворобу серця. Методи. Аналіз та узагальнення даних наукової та науково-методичної літератури. Результати. В Україні абсолютна більшість кардіологічних пацієнтів після виписування зі стаціонару не отримують переваг кардіореабілітації. Розвиток інформаційних технологій спонукав до використання телемоніторингу та впровадження програм телекардіореабілітації, які можуть бути ефективним рішенням для продовження реабілітаційної програми в домашніх умовах та сприяння догляду за пацієнтами протягом тривалого часу. Висновки. Недостатнє впровадження сучасних програм кардіореабілітації є нагальною проблемою в Україні. Засобом підвищення ефективності кардіореабілітаційних програм може бути впровадження новітніх інформаційних технологій у практику охорони здоров'я, що дозволить продовжувати реабілітацію хворих на IXC на амбулаторному етапі в домашніх умовах та збільшити прихильність пацієнтів до участі в реабілітаційних програмах.

Ключові слова: кардіореабілітація, ішемічна хвороба серця, фізична терапія, інформаційні технології, телереабілітація.
\end{abstract}

The use of modern information technology in cardiac rehabilitation: a review of foreign experience

\section{P. Kostenko, M. S. Balazh}

National University of Physical Education and Sport of Ukraine, Kyiv, Ukraine

Abstract. Objective. According to literature sources, to consider modern approaches to the possibility of using information technology in cardiac rehabilitation of patients with coronary heart disease (CHD). Methods. Analysis and synthesis of scientific and methodological literature. Results. In Ukraine, the vast majority of cardiac patients after discharge from the hospital do not receive the benefits of cardiac rehabilitation. The development of information technology has facilitated the use of telemonitoring and the introduction of telecardiorehabilitation programs, which may be an effective solution to continue the rehabilitation program at home and facilitate monitoring of patients for a long time. Conclusions. Insufficient implementation of modern cardiac rehabilitation programs is an urgent problem in Ukraine. The use of new information technologies in healthcare practice can be a means of increasing the effectiveness of cardiac rehabilitation programs, which will allow continuing rehabilitation of patients with coronary artery disease at the outpatient stage at home and increasing patients commitment to participate in rehabilitation programs.

Keywords: cardiorehabilitation, coronary heart disease, physical therapy, information technology, telerehabilitation.

Постановка проблеми. Серцево-судинні захворювання (ССЗ) серед усього населення України (за поширеністю) становлять 30,9 \% усіх захворювань серед дорослого населення віком від 18 років - 37,3 \%, серед працездатного населення $-24,2 \%$. При високому рівні захворюванос- ті, інвалідизація і смертність в Україні внаслідок хвороб системи кровообігу значно перевищує аналогічні показники в розвинених країнах [1].

Найбільше медико-соціальне навантаження серед кардіоваскулярних захворювань належить ішемічній хворобі серця (IXC) $[1,3]$. 
Сучасний підхід до реабілітації хворих на IXC передбачає включення пацієнтів до програми тривалих тренувань із фрізичним навантаженням та попередження, виявлення і корекцію кардіометаболічних фракторів ризику. Проте в Україні спостерігається недостатнє впровадження таких програм кардіореабілітації та вторинної профрілактики, спрямованих на покращення прогнозу та якості життя пацієнтів; особливе значення має фрактична відсутність амбулаторної реабілітації пацієнтів після гострих коронарних подій.

Враховуючи сучасні соціально-економічні умови, для підвищення ефективності кардіореабілітаційних програм перспективним напрямком досліджень $€$ розробка та впровадження новітніх інформаційних технологій, що дозволять вирішити проблему залучення пацієнтів до програм післялікарняної реабілітації, та вивчення їх впливу на показники поширеності та ускладнень серцевосудинних захворювань.

Зв'язок роботи $з$ важливими науковими програмами або практичними завданнями. Роботу виконано відповідно до плану НДР НУФВСУ на 2016-2020 рр. за темою 4.2. «Організаційні та теоретико-методичні основи фрізичної реабілітації осіб різних нозологічних, професійних та вікових груп» (номер держреєстрації 0116U001609).

Мета дослідження - за даними літературних джерел розглянути сучасні підходи до можливості застосування інфоомаційних технологій у кардіореабілітації хворих на ішемічну хворобу серця.

Методи дослідження - аналіз та узагальнення даних наукової та науково-методичної літератури.

Результати дослідження та їх обговорення. Реабілітаційні заходи - невід'ємна частина стандартів лікування кардіологічних хворих. Як й інші методи лікування, програми кардіореабілітації змінюються та еволюціонують, що підвищує їх ефективність.

Кардіореабілітація після серцево-судинних подій належить до доказового класу I згідно 3 рекомендаціями ESC, AHA, АCC. Доведено, що комплексна реабілітація, заснована на фрізичних тренуваннях та корекції фракторів ризику IXC (нераціональне харчування, ожиріння, куріння, гіподинамія, порушення вуглеводного та ліпідного обміну), $є$ одним із найважливіших засобів покращення прогнозу у хворих на IXC [12].

Однак, не зважаючи на це, в Україні абсолютна більшість кардіологічних пацієнтів не залучені до програм кардіореабілітації, що обумовлено рядом причин: зміна соціально-економічних умов, руйнування системи «стаціонар-санато- рій-диспансерно-поліклінічне спостереження», скорочення термінів госпіталізації і раннє виписування хворих 3 гострим інфрарктом міокарда, недостатність у пацієнтів фрінансів для проходження санаторно-курортного лікування, низька обізнаність лікарів та хворих щодо переваг кардіореабілітації, заснованої на застосуванні тривалих фрізичних тренувань тощо. Все це призводить до зростання числа серйозних ускладнень і летальних випадків серед пацієнтів, які виписались із кардіологічних відділень після гострої коронарної події.

Фактична відсутність післялікарняного етапу реабілітації хворих на IXC в Україні унеможливлює вирішення основних завдань кардіореабілітації: залучення хворих до тривалих програм фрізичних тренувань та впровадження заходів вторинної профрілактики, спрямованої на зниження інвалідизації та летальності серед хворих на IXC, а також відновлення фрізичної працездатності і якості життя хворих. Слід зазначити, що дана проблема не $\epsilon$ унікальною для України: в країнах із високим рівнем розвитку реабілітаційної допомоги кардіологічним хворим фахівці так само стурбовані низьким рівнем залученості пацієнтів до програм амбулаторної реабілітації. Так, за даними A. Peretti [15], лише від 13 до 40 \% загальної кількості пацієнтів із серцевими хворобами в Німеччині проходять кардіореабілітацію в рамках контрольованих програм. Пацієнти не приєднуються до програм реабілітації через труднощі в плануванні, далеку відстань до реабілітаційних центрів та небажання виконувати вправи в групі. У Великій Британії понад 60 \% хворих на ССЗ не отримують переваги кардіореабілітації зі схожих причин. Такий стан речей спонукав закордонних фрахівців до розробки, наукового обґрунтування та впровадження альтернативних моделей надання кардіореабілітаційної допомоги, зокрема розвитку общинних (community-based) програм та домашніх програм, заснованих на принципах телереабілітації та телемоніторингу.

Використання телемоніторингу та телереабілітації $€$ відносно новим, але дуже перспективним напрямом в кардіореабілітації. Порівняно 3 міждисциплінарними програмами втручання, реалізації яких часто перешкоджають економічні, географрічні та бюрократичні бар'єри, неінвазивний дистанційний моніторинг може бути рішенням для продовження реабілітаційної програми в домашніх умовах та сприяння догляду за пацієнтами протягом тривалого часу $[7,8,14]$.

Телереабілітація може розглядатися як галузь телемедицини. Хоча ця сорера $€$ відносно новою, іiї використання швидко розвивається в розвине- 
них країнах. Взагалі телереабілітація зменшує витрати як медичних працівників, так і пацієнтів порівняно з традиційною стаціонарною реабілітацією та реабілітацією. Крім того, пацієнти, які живуть у віддалених місцях, де традиційні послуги з реабілітації можуть бути важко доступними, можуть скористатися цією технологією [17].

В останні декілька років спостерігається прискорений розвиток напрямку телереабілітації завдяки розвитку нових інформаційних технологій та вдосконалення телемедичних пристроїв.

Телереабілітація була розроблена для догляду за пацієнтами після виписування їх зі стаціонару, щоб скоротити терміни госпіталізації та витрати пацієнтів та медичних працівників. Сьогодні комунікація на відстані легко досягається за допомогою відеоконференцій, електронної пошти та текстових повідомлень; існує можливість керувати робототехнічним обладнанням на відстані, завдяки чому останніми роками у всьому світі були розроблені нові практики реабілітації, які базуються на телекомунікаціях. Ці конкретні підходи в галузі реабілітації зазвичай визначаються як телереабілітація, яку слід розглядати як телемедичне підполе, що складається із системи управління реабілітацією на відстані [17].

Телереабілітація дозволяє лікувати гостру фазу захворювань, замінюючи традиційний підхід віч-на-віч у взаємодії пацієнт-реабілітолог. Також вона може охоплювати ситуації, в яких пацієнтам складно дістатися до традиційних реабілітаційних інфраструктур, розташованих далеко від місця їх проживання.

Досить часто телереабілітація асоціюється 3 іншими нереабілітаційними технологіями, такими, як віддалений моніторинг серцево-судинних параметрів, включаючи електрокардіограму (ЕКГ), артеріальний тиск та насичення крові киснем у пацієнтів із хронічними захворюваннями. Ці технології належать до іншої галузі телемедицини під назвою телемоніторинг, яка широко розвивається і використовується останніми роками.

Результати рандомізованих контрольованих досліджень останніх років [6, 9, 10, 13] свідчать про економічну ефективність програм кардіореабілітації, заснованих на застосуванні телереабілітації та телемоніторнигу, їх безпечність та сприятливий вплив на якість життя і корекцію факторів ризику, порівнювальний із впливом традиційних програм кардіореабілітації.

Водночас, слід пам'ятати, що телереабілітація як нове поле все ще проходить дослідження та розробки, і всі доступні програми тестуються лише для обмеженої кількості пацієнтів. Як і будь-яка технологія, телереабілітація має де- які переваги та недоліки. 3 точки зору переваг, системи домашньої телереабілітації є економічно ефективними, якщо втручання просто використовується для спостереження або оцінюваня пацієнтів під час фрізичної терапії. Можливість підтримувати зв'язок за допомогою телетехнологій дозволяє пацієнтам із серйозними патологіями проводити фрізичну терапію вдома, не здійснюючи втомлювальних подорожей. 3 точки зору недоліків, проблемою може бути втрата контакту пацієнта (взаємодія віч-на-віч) з реабілітологом. Більше того, для кожного пацієнта оператори системи зобов'язані оптимізувати телетерапію відповідно до типу захворювання, а іноді це неможливо через великі витрати [16].

Інший перспективний напрям підвищення ефрективності кардіореабілітаційних програм застосування спеціальних додатків для смартфонів, що дозволяють здійснювати контроль за дотриманням пацієнтами програм кардіореабілітації та вторинної профрілактики. Такі додатки можуть бути використані для відстеження фрізичних навантажень 3 інтерактивним зворотним зв'язком та встановленням цілей; містити навчальні модулі, які стосуються розуміння захворювання та самоконтролю; для дистанційного моніторингу артеріального тиску та контролю за дотриманням схеми прийому ліків тощо. Декілька рандомізованих контрольованих досліджень показали, що застосування подібних додатків у комплексних кардіореабілітаційних програмах підвищує мотивацію пацієнтів до виконання рекомендацій лікаря та фрахівця з реабілітації [11].

Про перспективність застосування інформаційних та комунікаційних технологій у кардіореабілітації свідчить впровадження Європейською спілкою кардіологів концепції «Цифрове здоров'я» (Digital Health), що відображає необхідність змін в організації та управлінні реабілітаційними послугами відповідно до сучасних реалій. Необхідність таких змін обумовлена такими чинниками:

- зміни в сфері охорони здоров'я (диджиталізація, зростаюча кількість нових медичних технологій);

- нестача та нерівномірний розподіл медичних працівників;

- нерівності у доступі до медичної допомоги;

- постарішання суспільства;

- збільшення поширеності хронічних захворювань;

- попит на більше залучення пацієнтів до програм лікування та реабілітації;

- фрінансовий тиск на системи охорони здоров'я; 
- широке використання цифрових додатків у повсякденному житті, що надає можливість вирішити деякі виклики, з якими стикається суспільство [5 ].

Таким чином, застосування новітніх інфоормаційних технологій у кардіореабілітації $€$ новою та цікавою сферою, але, на жаль, на даний момент не існує стандартних процедур чи протоколів, а різні телереабілітаційні засоби використовуються лише для пілотних досліджень. Все це свідчить про необхідність подальших наукових розвідок у даному напрямі, що дозволить значно підвищити ефективність реабілітаційної допомоги хворим на IXC.

Висновки. Недостатнє впровадження сучасних програм кардіореабілітації $€$ нагальною проб-

\section{Література}

1. Іпатов, АВ, Лисунець ОМ, Ханюкова ІЯ, Ткаченко ЮВ, Овдій МО, Зубко ІМ, Бірець НМ, Волкова ЛВ. Первинна інвалідність внаслідок провідних хвороб системи кровообігу в Україні [Primary disability as a result of major circulation diseases in Ukraine]. Буковинський медичний вісник. 2017; 21, 2 (82), ч. 1: 197-202.

2. Иващенко СН, Андрияш РО. Физическая реабилитация больных с ишемической болезнью сердца на амбулаторно-поликлиническом этапе [Physical rehabilitation of ischemic patients at outpatient-polyclinic stage]. Науковий часопис НПУ імені М.П. Драгоманова. 2016;1 (68):29-32.

3. Коваленко ВН, Долженко МН, Несукай ЕГ, Дьяченко ЯС. Сравнительная характеристика профилактики сердечно-сосудистых заболеваний в Украине и Еропе, по данным EUROASPIRE IV: госпитальная линия [Comparative characteristics of cardiovascular disease prevention in Europe and Ukraine according to EUROASPIRE IV data: hospital line]. Артериальная гипертензия. 2015;5(43):57-61.

4. Малиновская ИЭ, Шумаков ВА, Терещенко НМ. Ранняя постгоспитальная кардиореабилитация пациентов после инфраркта миокарда основа эфффективной вторичной профрилактики [Early posthospital cardiorehabilitation of patients after myocardial infarction - basis of efficient secondary prevention]. Український кардіологічний журнал. 2016. Додаток 1:16-25.

5. About Digital Health, https://www.escardio.org/Education/DigitalHealth-and-Cardiology/about-digital-health

6. Chan C, Yamabayashi C, Syed N, Kirkham A, Camp PG. Exercise Telemonitoring and Telerehabilitation Compared with Traditional Cardiac and Pulmonary Rehabilitation: A Systematic Review and Meta-Analysis. Physiother Can. 2016; 68(3): 242-251.

7. Gant RJ, Rolleston N, Whittaker A, Stewart R, Benatar R, Warren J. Ralph, M. End Users Want Alternative Intervention Delivery Models: Usability and Acceptability of the REMOTE-CR Exercise-Based Cardiac Telerehabilitation Program. Archives of Physical Medicine and Rehabilitation. 2018; 99. 10.1016/j. apmr.2018.06.027.

8. Gensini GF, Alderighi C, Rasoini R, Mazzanti M, Casolo G. Value of Telemonitoring and Telemedicine in Heart Failure Management. Card Fail Rev. Nov, 2017; 3(2): 116-121. doi: 10.15420/cfr.2017:6:2. лемою в Україні. Засобом підвищення ефективності кардіореабілітаційних програм може бути впровадження новітніх інформаційних технологій в практику охорони здоров'я, що дозволить продовжувати реабілітацію хворих на IXC на амбулаторному етапі в домашніх умовах та збільшити прихильність пацієнтів до участі в реабілітаційних програмах.

Перспективи подальших досліджень полягають у науковому обґрунтуванні та розробці алгоритму застосування методів комплексної реабілітації та вторинної профрілактики із використанням сучасних інорормаційних технологій для хворих на IXC на амбулаторному етапі лікування.

9. Hwang R, Bruning J, Morris N, Mandrusiak A, Russell T. J. (2015) A Systematic Review of the Effects of Telerehabilitation in Patients With Cardiopulmonary Diseases. Cardiopulm Rehabil Prev. 2015; 35(6):380-9. doi: 10.1097/ HCR.0000000000000121.

10. Hwang R, Morris NR, Mandrusiak A, Bruning J, Peters R, Korczyk D, Russell T. Cost-Utility Analysis of Home-Based Telerehabilitation Compared With Centre-Based Rehabilitation in Patients With Heart Failure. Heart Lung Circ. Dec. 2018; 28(12): 1795-1803. doi: 10.1016/j.hlc.2018.11.010.

11. Kim JS, Yun D, Kim HJ, Ryu HY, Oh J, Kang SM. Need Assessment for Smartphone-Based Cardiac Telerehabilitation. Healthc Inform Res. 2018. Oct; 24(4):283-91. doi: 10.4258/hir.2018.24.4.283

12. Long L, Anderson L, Dewhirst AM, He J, Bridges C, Gandhi M, Taylor RS. Exercise-based cardiac rehabilitation for adults with stable angina. Cochrane Database of Systematic Reviews. 2018. Issue 2. Art. No.: CD012786. DOI: 10.1002/14651858.CD012786.pub2.

13. Maddison R, Rawstorn JC, Stewart RAH, Benatar J, Whittaker R Rolleston A, Jiang Y, Gao L, Moodie M, Warren I, Meads A, Gant N. Effects and costs of real-time cardiac telerehabilitation: randomised controlled noninferiority trial. Heart. 2019, Jan;105(2):122-29. doi: 10.1136/heartjnl-2018 313189.

14. Peng X, Su Y, Hu Z, Sun X, Li X, Dolansky MA, Qu M, Hu X. Homebased telehealth exercise training program in Chinese patients with heart failure: A randomized controlled trial. 2018 Aug, 97(35), e12069. doi: 10.1097/ MD.0000000000012069.

15. Peretti A, Amenta F, Tayebati SK, Nittari G, Mahdi SS. (2017). Telerehabilitation: Review of the State-of-the-Art and Areas of Application. JMIR Rehabil Assist Technol. 2017 Jul 21;4(2):e7. doi: 10.2196/rehab.7511.

16. Vaughan N, Gabrys B, Dubey V. An overview of self-adaptive technologies within virtual reality training. Comput Sci Rev. 2016 Nov; 22:65-87. doi: 10.1016/j.cosrev.2016.09.001.

17. Zampolini M, Todeschini E, Bernabeu GM, Hermens H, Ilsbroukx S, Macellari Giacomozzi C. Telerehabilitation: present and future. Ann Ist Super Sanita. 2008; 44(2):12534. http://www.iss.it/publ/anna/2008/2/442125.pdf. 